\title{
EPOXY RESIN AND RELEASE AGENTS PART I: INFLENCE OF EXTERNAL AND INTERNAL RELEASE AGENTS ON THE ADHESIVE PROPERTIES OF EPOXY RESIN
}

\author{
Dr Robert Bjeković \\ University of Applied Sciences in Ravensburg- Weingarten, Germany \\ Kinga Piotrowicz \\ University of Applied Sciences in Ravensburg- Weingarten, Germany
}

A wide range of epoxy resins are molded to produce composite components for various applications. Release agents are generally used to facilitate the removal of the component from the mold. The work presented in this paper shows differences between release agents and resin during a RTM process. Adhesive properties of release agents in interaction with the resin are analyzed, with respect to pressure and temperature. It was found that the reaction of epoxy resin results indifferent breakaway forces from mould surfacesdepending on used agents.

Keywords:Epoxy resin, internal and external release agent, RTM (Resin transfer molding) process

\section{INTRODUCTION}

Epoxy resin isone of the most important polymers, with applications in such fields asstructural adhesives, surface coatings, composite materials and electronic devices and so on [03]. The interest in epoxy resins is related to their attractive characteristics, including small shrinkage during curing, good adhesion to substrates and electrical and mechanical resistance [13]. Moreover, epoxy resins have good thermal, dimensional, as well as electrical stability and, chemical resistance.[03,05].Epoxy composites market is very fast evolving particularly for the high- performance composites. This is characteristic in the automotive industry for short cycle time as challenge for mass production [16]. The resin transfer molding (RTM) process is one of the widely used manufacturing process of composite structures in the industry of transport (e.g. automotive) and aircraft [16]. Lately that process has more attention in industry of many advantages [02].The material cost with RTM is much lower than with prepreg technology. It creates a compromise in comparison of manual lamination, autoclave molding and RTM process in terms of requirements, productivity and quality [10]. The typical RTM process cycle consists of four phases:

- The $1^{\text {st }}$ phase is preform manufacturing which produces the fiber reinforcement in the shape of the finished part.

- The $2^{\text {nd }}$ phase is mold filling during which resin in injected into the cavity of a mold containing the preplaced preform.

- The $3^{\text {rd }}$ phase is resin curing which may start during or after the second phase.

- The $4^{\text {th }}$ phase is demolding which occurs after the curing reaction comes to completion and the part solidifies [01].

One of the important points of resin compositesis to select release agents properly according to interactions between resin and both mold surfaces and fibers. Most often these components are either mixtures of esters, waxes, zinc and calcium stearates or fluorocarbon and silicon complexes [09]. Polymeric components are molded to particular shapes and release agents are used to facilitate removal of the component from the mold [15]. The agent creates a very low surface energy coating on a substrate, which allows the shaped material to be released quickly and easy.Applied release agent causes elimination or reduction of adhesion on the surface of the mold, which is often difficult to achieve $[14,17]$. A well preparation and precise application of these products during manufacturing process is very important. It takes time to prepare a clean surface of the mold faultlessly and the right amount of agent has to be applied. To be effective, the surface must be cleaned thoroughly to remove all traces of oils,

*Hochschule Ravensburg-Weingarten - University of applied sciences, Gebäude H, Raum H022, Doggenriedstr., 88250 Weingarten; 45 
,waxes or other impurities [04]. Release agents can be divided into two groups: external- products which are applied on the mold surface; and internal- which are combined with the resin system. Application of external release agentsis critical in ensuring their optimal performance. It can be applied by hand or using spray equipment. Traditional agents with problems that have already been resolved like safety concerns due to environmental and health issues have led to new alternative water-based products. The major disadvantage of the water-based release agents is a long time of evaporation and it is recommended to use them with heated molds. The recent alternative is to use a semi- permanent release agent [12], which are reactive resin solutions designed to cross- link and cure on the mold, providing inert release films $[11,12]$.

Internal release agents are combined with the resin prior to molding. The agent is dissolved in the mixed resin. The time to apply an external agent on the surface compared to an internal agent is eliminated from the production process. One main advantage of this type of release agents is robustness of processfor high volume manufacturing[12].

This paper presents the differences between the impact of the external and internal release agents on the epoxy resins of the molding polymer. In practice,there are no suitable toolswhich can effectively classify effects of release agents. Moreover, the influence of release agents on adhesion between mold surface and epoxy resin is investigated. The aim of this work was to identify suitable release agents for epoxy resins.

\section{EXPERIMENTAL}

\section{Materials used}

A standard epoxy resin of bisphenol- A (epichlorhydrin) type, suitable for construction and industry, with an average molecular weight of 700 , supplied by Sika ${ }^{\circledR}$, was used. The hardener 3aminomethyl- 3, 5, 5- trimethylcyclohexylamine, 2- piperazin- 1- ylethylamine, was modified by weightin a ratio of 100 to 24 .

All release agents used in this paper are characterized in Table 1.

\section{Preparation}

All samples were prepared by mixing a formulation of resin and hardener.

External release agent was applied to mold surface at room temperature. The mold was covered by triple coating layer of an external agent. Before

Table 1: Characterisation of release agents.

\begin{tabular}{|c|c|}
\hline Producer/ Provider & Products \\
\hline \multicolumn{2}{|l|}{ External release agent } \\
\hline $\begin{array}{l}\text { Axel Plastics Research Laboratories } \\
\text { Ins (www.axelplastics.com) }\end{array}$ & XTEND 19RBU®- semi- permanent releases. \\
\hline $\begin{array}{l}\text { Chem- Trend } \\
\text { (www.chemtrend.com) }\end{array}$ & $\begin{array}{l}\text { Mold Sealer S-31® and Treil Part 310®-semi- per- } \\
\text { manent release agents. }\end{array}$ \\
\hline $\begin{array}{l}\text { Hacotech } \\
\text { (www.hacotech.com) }\end{array}$ & Hacowax $T 1 \circledR$ - external release agent. \\
\hline $\begin{array}{l}\text { Henkel } \\
\text { (www.henkelna.com) }\end{array}$ & $\begin{array}{l}\text { Frekote } 55 \mathrm{NC} \otimes \text {, Frekote } 700 \mathrm{NC} \otimes \text { and Frekote } \\
770 \circledast \text { - semi- permanent release agents. }\end{array}$ \\
\hline $\begin{array}{l}\text { KVS Eckert \& Woelk } \\
\text { (www.kvsewo.de) }\end{array}$ & $\begin{array}{l}\text { EWOmold } 3721 \circledast \text { and VP } 094491 \circledast \text { - external re- } \\
\text { lease agents. }\end{array}$ \\
\hline $\begin{array}{l}\text { Muench Chemie Internalional } \\
\text { (www.muench-chemie.com) }\end{array}$ & $\begin{array}{l}\text { Mikon } 705 \mathrm{MC} \circledast \text {, Mikon } 34+\AA \text { and Mikon W } 38+\AA- \\
\text { semi- permanent release agents. }\end{array}$ \\
\hline $\begin{array}{l}\text { Zyvax Inc } \\
\text { (www.zyvax.com) }\end{array}$ & $\begin{array}{l}\text { Watershield } \circledast \text { and Enviroshield } ® \text { - solvent- free } \\
\text { semi- permanent release agents. }\end{array}$ \\
\hline \multicolumn{2}{|l|}{ Internal release agent } \\
\hline $\begin{array}{l}\text { WELA Handelsgesellschaft } \\
\text { (www.wela-handelsgesellschaft.de) }\end{array}$ & $\begin{array}{l}\text { Additive G- } 161 @ \text { and Additive G- } 161 @ \text { - internal } \\
\text { release agents. }\end{array}$ \\
\hline $\begin{array}{l}\text { E. and p. Wuertz \& Co KG } \\
\text { (www.epwuertz.de) }\end{array}$ & $\begin{array}{l}\text { PAT@657/ BW@ and PAT®657/ BW- internal release } \\
\text { agents. }\end{array}$ \\
\hline
\end{tabular}


applying an external release agent the surface has been thoroughly cleaned (Figure 1a). The sealer sealedeffectively all micro porosityon the tool surface (Figure 1b). The release agent was applied as a smooth wet film over an area in accordance to the specific instructions (Figure 1c).

The internal release agents were mixed with epoxy resin and hardener. The added amount of agents ( $1 \mathrm{vol} \%, 2 \mathrm{vol} \%, 3 \mathrm{vol} \%$ and $5 \mathrm{vol} \%)$ is related to the final mixture. For every test a $2 \mathrm{~g}$ sample was prepared. The samples were exposed at temperature of $80^{\circ} \mathrm{C}$ and pressure of $1 \mathrm{MPa}$ and were cured for $20 \mathrm{~min}$. To facilitate the cleaning of the mold's surface Surface Cleaner $\AA$ and Mold Cleaner \#3® were usedto clean surfaces after every test. The epoxy resin was applied on the molds surface (diameter $90 \mathrm{~mm}$ ). The used material was grinded steel (Figure 2b).

\section{Testing method}

To test the external and internal release agent special geometrywas designed and integrated in the testing machine (Figure 2a). Base design is similar to the approach of University of Bayreuth [09].

Tests were carried out on an universal testing machine model Instron 5567 under controlled atmosphere conditions $\left(23^{\circ} \mathrm{C} \pm 2 \mathrm{~K}\right)$ and a crosshead speed of $1 \mathrm{~mm} / \mathrm{min}-1$. Inside the mold, there were two heating elements (bottom and top) and one sensor PT100 in each plate to control temperature (Figure 2b).
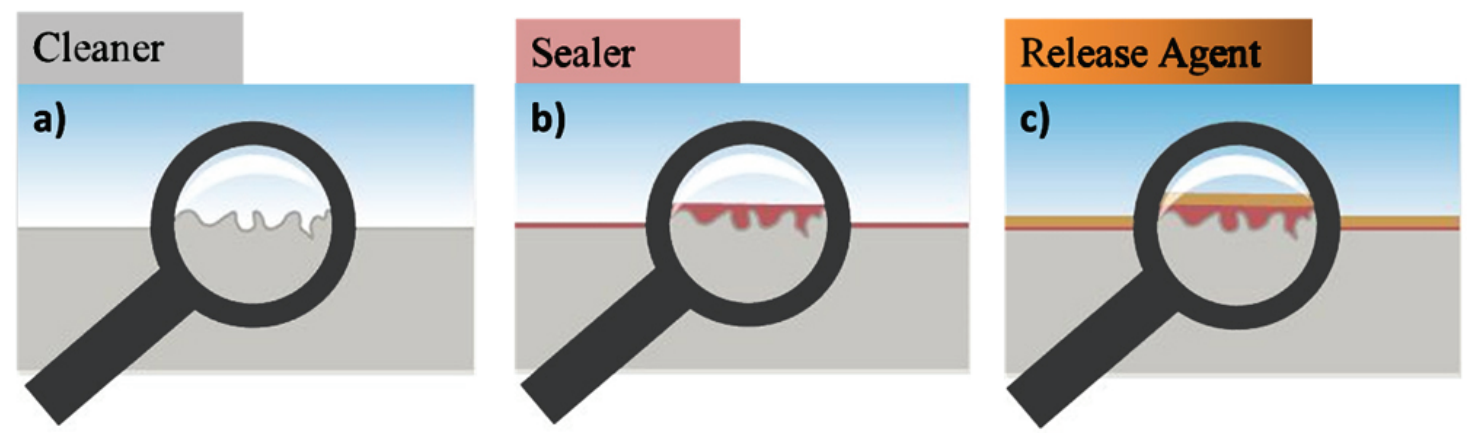

Figure 1: Applying the release agent on the surface: a) cleaner, b) sealer and c) release agent [16].
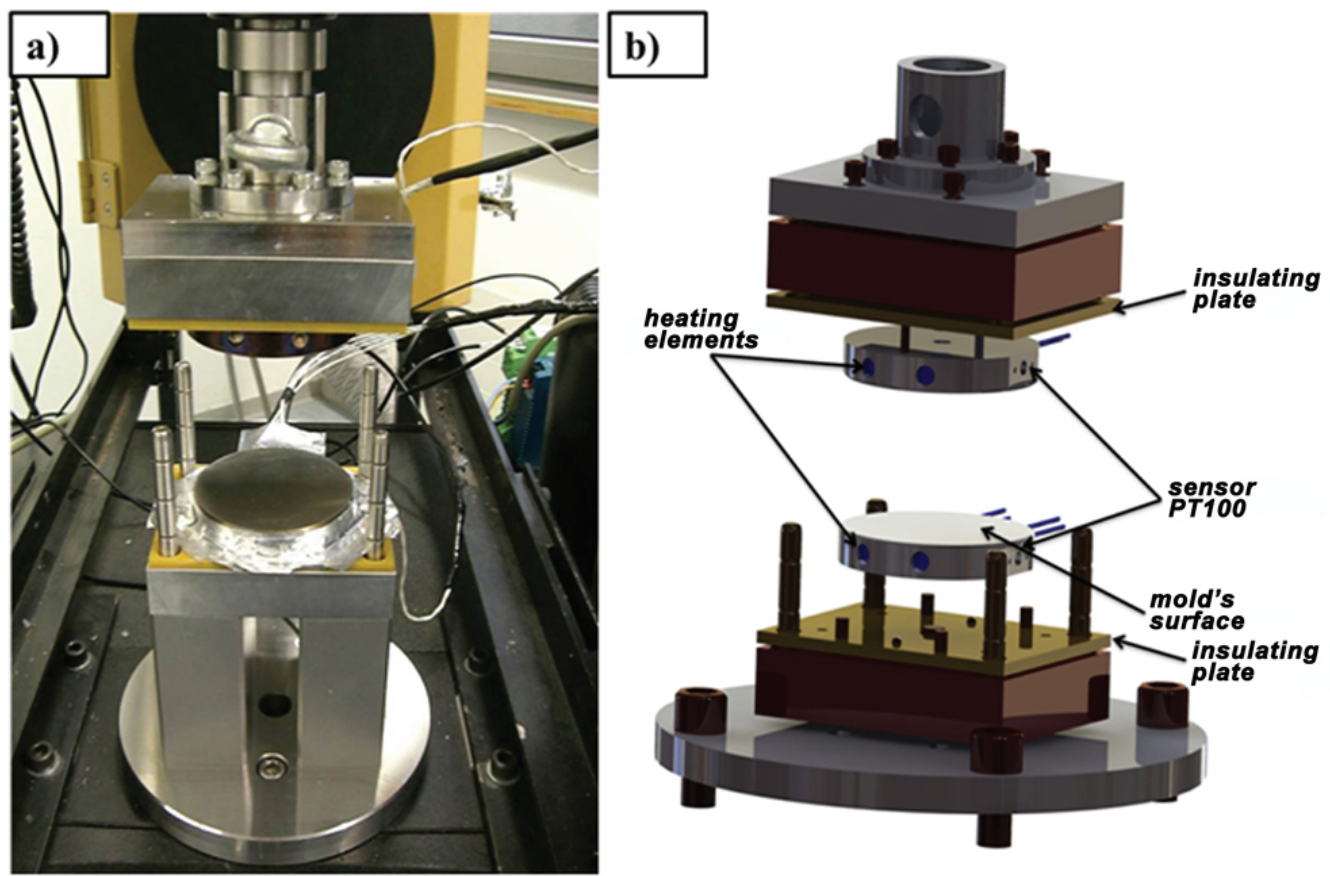

Figure 2: An instruments a) Instron 5567 used for measurement, b) image of test stand in SolidWorks. 
All components were connected with the heating deviceas shown in (Figure 3).

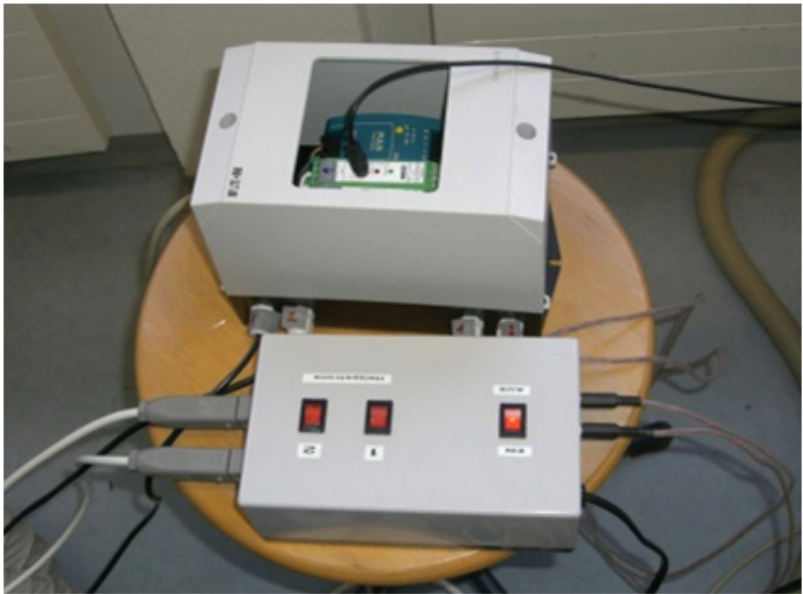

Figure 3: The heating device for heating elements and sensors

The temperature accuracy between the mold surfaces was $80^{\circ} \mathrm{C} \pm 2 \mathrm{~K}$ (Figure 4). The epoxy resin was applied, after mixing, to the bottom part. Defined distance between two mold surfaces was $0.5-0.7 \mathrm{~mm}$. After completing, the epoxy resin has to be separated from the mold surface.

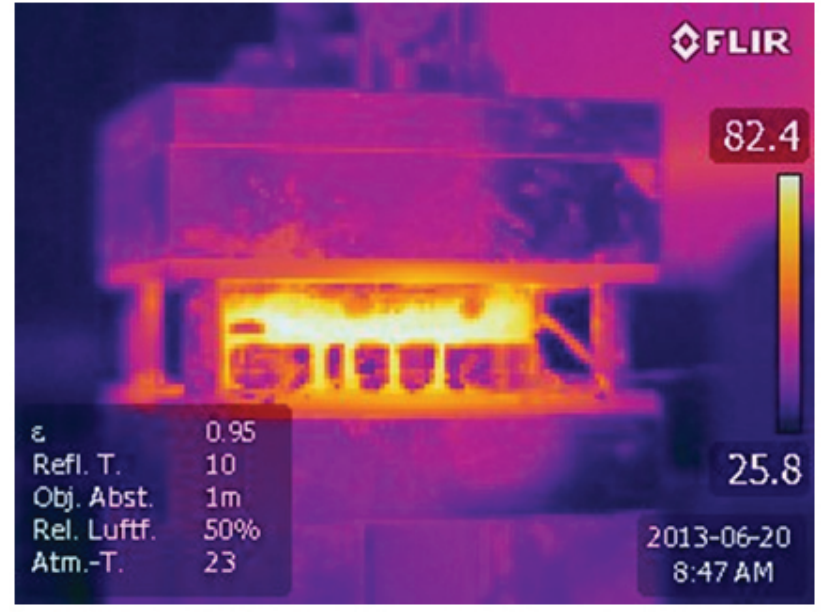

Figure 4: Thermographic image of the heating surfaces

\section{RESULTS AND DISCUSSION}

The analysis allowed determination of influence both of the external and internal release agents on the behavior of a resin systemin automated industrial processing. The differences in demolding forces emphasize that chemistry (which is usually not ordinarily known), must be considered for each system.

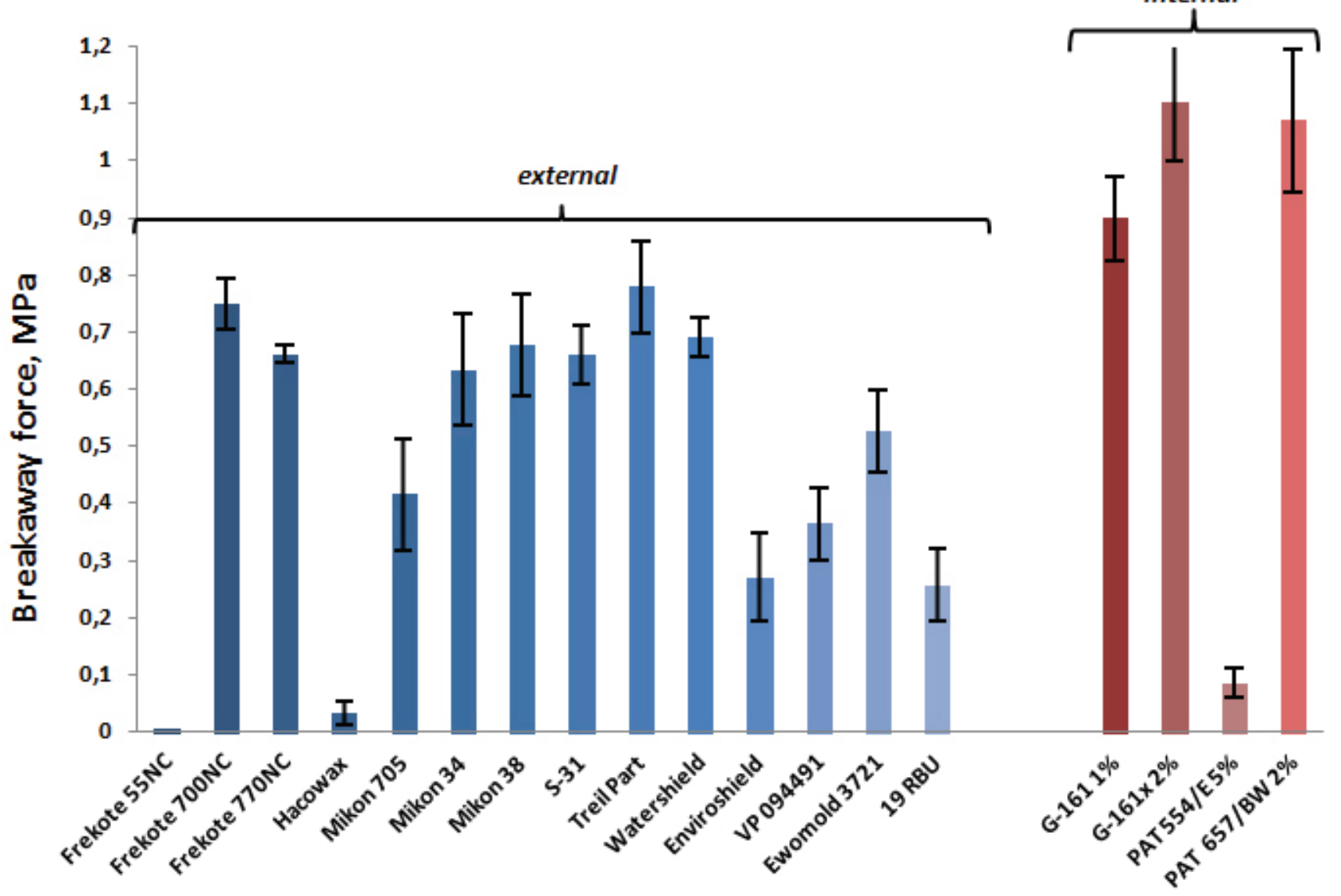

Figure 5: Breakaway force compared to different external and internal release agents 


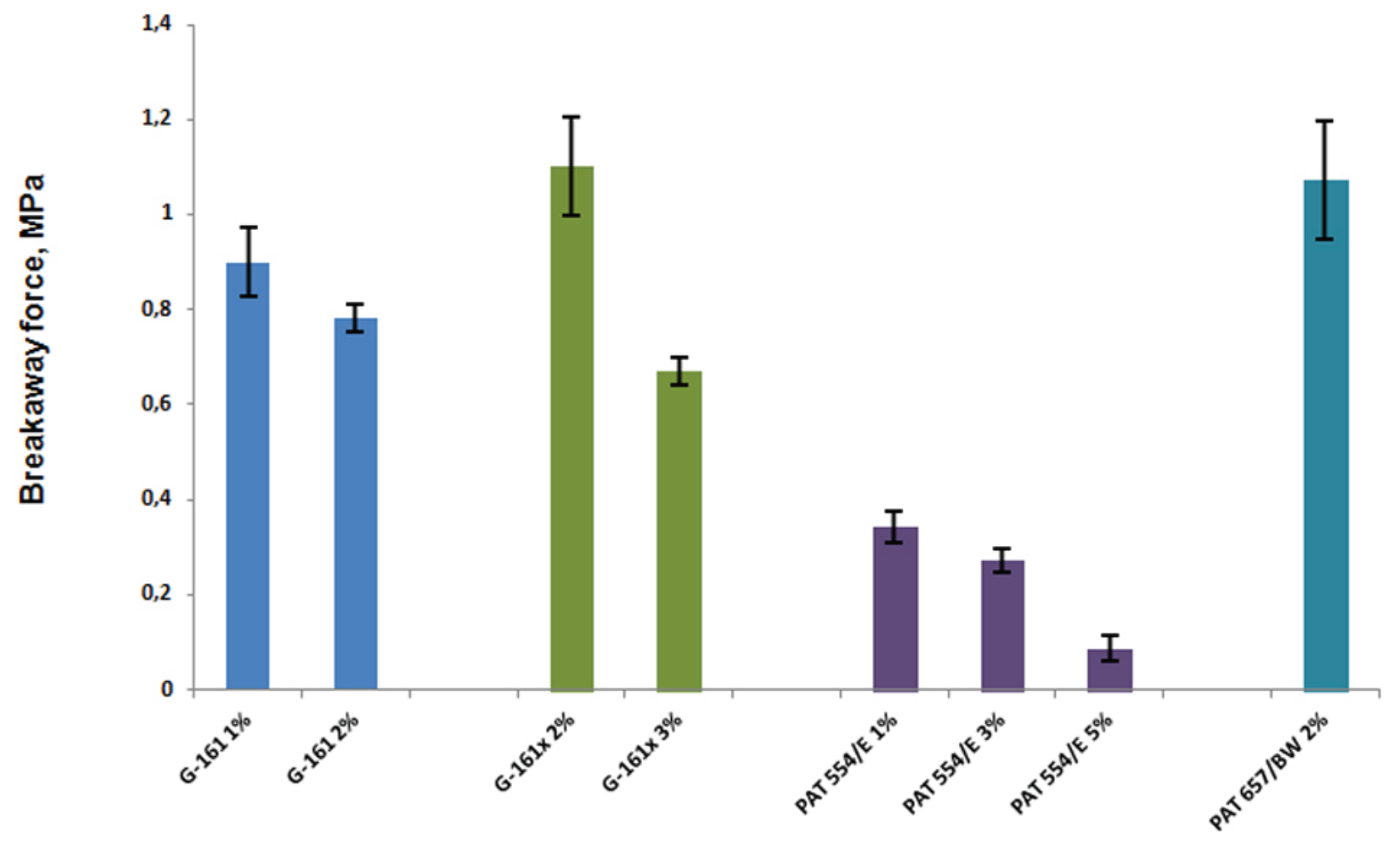

Realise agents and concetration

Figure 6: Breakaway force with different concentration of $\%$ internal release agents

However, after the same time, the external release agent was not on the mold surface and the application process took time. Due to the impossibility of preforming measurements, the fact that all applied coat were different, needs to be taken into consideration. The assessment show that the presented method does not allow obtaining reproducible thickness of coatings.

It was proved that only one internal release agent PAT 554E with $5 \%$ of concentration is comparable to external release agents. In can be observed that Frekote $55 \mathrm{NC}$ of $0,0045 \mathrm{MPa}$ shows the low surface energy on a surface to compared Frekote $700 \mathrm{NC}$ of $0,74 \mathrm{MPa}$.

The below-presented graph demonstrates that not every release agent is suitable for this epoxy resin.

Figure 5 presents different amount 1\%, 2\%, 3\% and $5 \%$ of internal release agents. The higher $\%$ concentration is determined by producer. There is a clearly defined pattern to the graph, and this can be taken to mean that with higher amount of $\%$ is the lowest surface energy. Nevertheless, Fig. 6 shows that minimum and maximum concentration of release agent has a influence on the results. Moreover, the release agent PAT 554 $E$ of $5 \%$ presents the lowest energy on surface under force of $0,08 \mathrm{MPa}$. The release agent PAT $554 \mathrm{E}(1 \%, 3 \%, 5 \%)$ shows the best result compared to G-161, G-161x and PAT 657 BW.

\section{CONCLUSION}

This paper presents the influence of the external and internal release agents on the breakaway force of the bisphenol- A (epichlorhydrin) epoxy resin. The results clearly show that it is impossible to find an universal release agent for the epoxy resin. The difference between two release agents shows that only one of the external and internal release agent can create a very low surface energy on a substrate. It is shown that concentration of \% internal release agent has a considerable impact on the results. With the rise of content of the internal release agent then decreases the value of force acting on the surface. However, repetition of the same \% content of the agent does not correspond to the comparable result with the other agent. It depends on the chemical composition of substance, which is usually not given by manufacturer and on the chemical composition of resin with which it is used. Designation of external and internal release agent into existing reactive epoxy resin is an im portant step towards process automation. 
Future work will be focused on the testing of different adhesive agents using a wide range of surfaces, higher temperatures and comparison of the similar epoxy resin to the one presented in this paper.

\section{ACKNOWLEDGEMENTS}

The authors would like to thank The Europe Union - Europäischer Fondsfürregionale Entwicklung (EFRE) - and Baden- Württemberg for their support.

\section{REFERENCES}

1) Advani S. G., Brusche M. V., Parnas R., Flow and rheology in Polymeric Composites Manufacturing , (Ed. Advani S. G), Elsevier, Amsterdam 1994, pp. 466- 479

2) Archim V., Ruiz E., Int J Master Form 2009,3 (S2), pp. 1277-1286

3) Coscaval C. N., Rosu D., Mititelu- Mija A., Rosu L., Polimery 2006, 51, pp. 199-205

4) Goss B., Reinforced Plastics 2004, 8, pp. 24-26

5) Hodkin J. H., Simon G. P., Varley R. J., Polym. Adv. Technol. 1998, 9, pp. 3-10

6) http://www.lange-ritter.de/fileadmin/user upload/Downloads/Produkte/Diverses/L_R Katalog_2013_Diverses_Formentrennmittel.pdf (access 2013)

7) Kang M. K., Jung J. J., Lee W. I., Composites Part A 2000, 31(5), pp. 407- 422
8) Karbhari M. V., Journal of material science letters 1998, 17, pp.2061-2062

9) Krämer J., Hähnel M., Fabris W., Altstädt V., ,Classification of internal release agentsEvaluation of test facility and the effect on the neat epoxy resin properties", Thermosets, Berlin, Germany, 22 September, 2011

10) Naik K. N., Sirish A., Inani A., Progress in Aerospace Sciences 2014, 65, pp. 22-40

11) Plastic, Additives and Compoulding, Volume 1, Issue 1, April- May 1999

12) Reinforced Plastics, Volume 52, Issue 7, July- August 2008

13) Rosu L., Ciobanu C., Rosu D., Polimery 2008, 53, pp. 644-648

14)Scyidow F. T., Mansoori Y., TaghiNezhad J., Industrial Lubrication and Tribology2007,pp.236-241

15)Shield A. J, Hpburn D. M., Kemp J., Cooper J. M., Polymer Degradation and Stability 2000, 70, pp.253- 258

16)Workshop, Leichtbaufertigung mit Faserbundwerkstoffen, Ditzingen, Germany, 20 November, 2012

17) Würtz J., , ,Leistungs- und Qualitätssteigerung in der Serienproduktion durch interne Trennmittel“, 17 Nationales Symposium SAMPE Deutschland e. V- Hochleistung und Großserie, Aacheln, Germany, 16-17 February, 2011

Paper sent to revision: 27.11.2014.

Paper ready for publication: 12.03.2015. 